\title{
Marketing Communication Program Design of Online Travel Agent Kliktrip Using Benchmarking and Analytical Hierarchy Process Methods
}

\author{
Alviera Suci Damayanti ${ }^{1 *}$, Sari Wulandari ${ }^{2}$, Meldi Rendra ${ }^{3}$ \\ 1,2,3 Telkom University \\ J1. Telekomunikasi No. 1, Bandung, 40258, Indonesia \\ *alvierasuci.viera@gmail.com
}

\section{ARTICLE INFO}

Article history:

Received 01 July 2021

Accepted 29 July 2021

Published 21 July 2021

Keywords:

Analytical Hierarchy

Process, Benchmarking,

Integrated Marketing

Communication, Marketing

Communication Mix, Online

Travel Agent.

\section{ABSTRACT}

Kliktrip is an Online Travel Agent (OTA) that has trip \& activities facilities and was established in 2018 in Bandung. Kliktrip sales are still experiencing a decline due to low public awareness of Kliktrip which is seen through the number of downloads on mobile apps and Instagram followers. Kliktrip sales are still experiencing a decline and public awareness of Kliktrip is still low because Kliktrip has not implemented 7 out of 8 marketing communication mix optimally. Therefore, research was conducted to design an effective marketing communication program for Kliktrip by using benchmarking and Analytical Hierarchy Process (AHP) methods. Based on the results of AHP data processing, it can be seen that the selected benchmark partner is Explorer.id with a total priority vector value of 0.44 and benchmark results with Explorer.id concluded that Kliktrip needs to increases the value of SEO, page views, and unique visitors on the website, creates a Tiktok's account, webisode, and video podcasting, collaborates with cross-promotion, makes contests (giveaways), increase the number of downloads and reviewers on mobile apps, implementing mobile billboards and causerelated marketing, increasing customer service operational time, participating in exhibitions, and collaborating with influencers.

\section{Introduction}

Tourism is a sector that has contributed greatly to economic growth in Indonesia in recent years [1]. However, this condition is not in line with tourism conditions in 2020 because the Covid-19 pandemic that was present in Indonesia in March 2020 had a detrimental impact on all types of business sectors, especially in the travel/tourism sector. Based on the Tech in Asia survey in 2020 [2] regarding the level of the negative impact of the Covid-19 pandemic on several startup sectors, it is known that the travel/tourism sector is the startup sector with the highest negative impact. In tackling the increasingly massive spread of Covid-19, the government imposed Large-Scale Social Restrictions (PSBB) in Government Regulation No. 21 of 2020. During the implementation of the PSBB, people experienced boredom because they had to stay at home for months. During the implementation of the PSBB, people experienced boredom because they had to stay at home for months. The boredom felt by most people, makes people want to travel to release boredom. Based on the Alvara Research Centre survey in 2020 [3] the activity that people really want after the Covid-19 pandemic is going to tourist attractions and provides a great opportunity for the tourism business sector to start resurrecting its business. In addition, PSBB has also changed the way people do all activities online. This all-online activity shows that 
digital media and technology have led people to a new life or "New Normal" so that various business sectors, especially the tourism business sector, which is predicted to start increasing in 2021 [4], need to prepare technology-based businesses. One of the tourism businesses in Indonesia that are already technology-based is Kliktrip. Kliktrip is an Online Travel Agent (OTA) that has trip \& activities facilities and was established in 2018 in Bandung. Kliktrip sells its products through mobile apps and websites, but Kliktrip's revenue through mobile apps and websites still experiences a downward trend from January 2018 to December 2019 as shown in Figure 3.

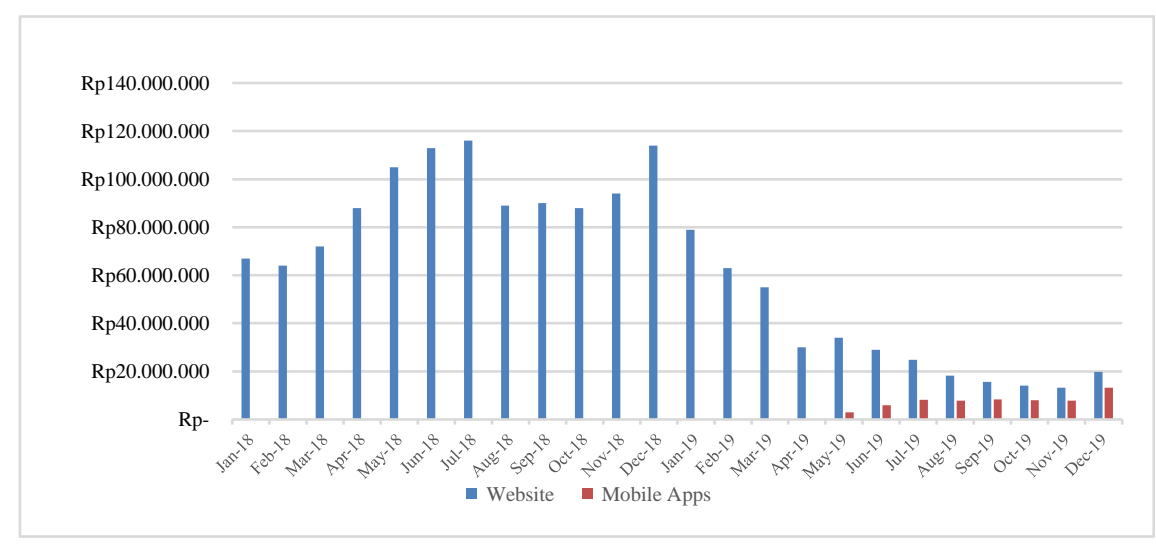

Fig. 1 - Kliktrip's Revenue

Kliktrip's overall downward trend in revenue and the lack of revenue from mobile apps is influenced by several factors, one of which is competitive pressure from the popularity aspect. Kliktrip's competitors include Mister Aladin, Explorer. id, and Vizitrip. The three competitors will become alternative benchmark partners in this research because they have the same market segment as people aged 20-40 years who want to go on vacation, have the same sales methods online, and have similar products in the form of trips and activities.

The number of downloads indicates the popularity of mobile applications (mobile apps) [5]. Based on Table 1 regarding the comparison of the number of downloaders between Kliktrip and its competitors, it is known that Kliktrip is in the last rank with the lowest number of downloads compared to the other two competitors. The low popularity based on the number of downloads is caused by Kliktrip's low heart share. The comparison of the number of heart shares based on the number of Instagram followers between Kliktrip and competitors can be seen in Table 2.

Table 1 - Comparison of Downloads, Instagram Followers, and Engagement Rate

\begin{tabular}{|c|c|c|c|c|}
\hline No & Company Name & Number of Downloads & Number of Followers & Engagement Rate \\
\hline 1. & Explorer.id & $1.000 .000+$ & 84.900 & $0.82 \%$ \\
\hline 2. & Mister Aladin & $50.000+$ & 31.500 & $0.17 \%$ \\
\hline 3. & Vizitrip & - & 27.700 & $0.08 \%$ \\
\hline 4. & Kliktrip & $100+$ & 8.182 & $0.14 \%$ \\
\hline
\end{tabular}

Based on Table 1 regarding the comparison of the number of Instagram followers of Kliktrip and its competitors, it shows that Kliktrip is in the last rank with the lowest number of followers at 8,401 . Then the number of followers is validated using the engagement rate value because the engagement rate can indicate the level of interaction and engagement of followers in a post on an Instagram account [6]. Kliktrip's engagement rate is $0.14 \%$ which can be classified at a low level, while with a Kliktrip number of 8,182 followers, Kliktrip should get an engagement rate above $4.98 \%$ to be classified as a good or high level [6]. Therefore, it can be concluded that the number of followers and the low engagement rate indicate that Kliktrip has a low number of heart shares so that it will have an impact on low market share and profitability [7].

The low heart share is because the company has not integrated all marketing communication platforms effectively [7]. Kliktrip has implemented 7 of 8 marketing communication mixes, including advertising, sales promotion, events and experiences, public relations and publicity, online marketing, and social media, mobile marketing, and direct and database marketing, but the seven marketing communication mixes have not had a significant impact on revenue and brand awareness or popularity, so it can be concluded based on the analysis of existing data that the root cause of the low revenue of Kliktrip is because it has not implemented an effective marketing communication program. Methods that can be used to improve ineffective marketing communication programs are benchmarking and Analytical Hierarchy Process (AHP). The AHP method in this study is to solve complex problems by choosing a benchmark partner. While benchmarking is used to find out the best practices of benchmark partners. Benchmarking and AHP methods have been popularly used in several studies to design marketing communication program improvements, including Imran et al [8], Firdhausya et al [9], Putra et al [10], and Wulandari et al [11]. Imran et al [8] utilized benchmarking and AHP methods 
to improve marketing communication on fashion SMEs Bearpath sandal object. On the other hand, Firdhausya et al [9] used benchmarking and AHP methods to improve marketing communication on online music streaming service Langit Musik object. Then, Putra et al [10] applied benchmarking and AHP methods to improve marketing communication on fashion SMEs Levaya bag object. Another relevant study was conducted by Wulandari et al [11] which explained the selection of benchmark partners using AHP on fashion SMEs Cotton.Go object. In addition, benchmarking and AHP are also widely used on different objects and problems by Singh et al [12], Strojny [13], Singh [14], Jabar et al [15], Kouatli [16]. Singh et al [12] implement AHP and benchmarking methods to help provide effective systematic decision support on the automobile car service industry in India. While Strojny [13] utilized AHP dan benchmarking methods to support the presentation of strategic analysis mechanisms on Polish public administration. Other than that, Singh [14] used AHP and benchmarking method to improve airline service quality. Then, Jabar et al [15] applied AHP and benchmarking methods to compare service quality, financial performance, and quality management systems in hospitality. Other research conducted by Kouatli [16] developed AHP and benchmarking methods to identify the best alternative from different business units as a mechanism of enhancing the motivation of intermingled people-process overall competitiveness. Besides that, Mura and Sharif [17] used the benchmarking process on tourism website objects to evaluate and compare website quality with other websites, while Sadeghpour et al [18] used the AHP method in the marketing field with the object of Ghavamin Bank Mazandaran to determine a good marketing strategy.

Based on the results of the literature study, it was found that there is a research gap that research on improving marketing communications on Online Travel Agent objects using benchmarking and analytical hierarchy process methods is still very limited, so this study was made to fill the research gap that aims to design an effective marketing communication program using benchmarking and AHP. Through this design, Kliktrip will have a good influence on revenue and brand awareness [7].

\section{Literature Study}

\subsection{Integrated Marketing Communication for Startup Company}

Integrated marketing communications (IMC) is the coordination and integration of all marketing communication tools, avenues, and sources into a program designed to maximize impact on consumers and stakeholders [19]. Integrated marketing communications have several roles, including unifying strategies and messages through multiple channels, connecting with multiple audiences, creating meaningful insights, delivering maximum impact, and shortening time [19]. The application of integrated marketing communication has been carried out in research with startup objects by AlMinhas [20]. Al-Minhas [20] found that startups need to improve communication skills, competitors' strategies, and the budget in implementing effective IMC. Although considering IMC strategies carried out by competitors is useful, companies need to consider innovative methods to be developed in their companies. Al-Minhas [20] has interviewed 12 Qatar startups, thought that budget will have a direct role in IMC's effectiveness. In addition, all of the startups thought that $80 \%$ of the success of IMC was reflected in the sales or revenues and market share that they had.

\subsection{Benchmarking and AHP in Integrated Marketing Communication}

Benchmarking is a company's learning process to identify best practices from other companies that produce the maximum results. Benchmarking consists of several types, namely internal benchmarking, competitive benchmarking, industry benchmarking, and generic benchmarking [17]. The type of benchmarking used in this study is a competitive benchmark because it has a goal to compare the company with competitors who have the same market [14] and the purpose of competitive benchmarking in accordance with the objectives of this study is to find out the best practices of Kliktrip competitors who have the same market. The benchmarking process is divided into 5 stages [21]: (1) Identify the object of study, (2) Select the benchmarking partner, (3) Collect and analyze data, (4) Design performance goals for improvement, (5) Implement plans and monitor results.

The Analytical Hierarchy Process (AHP) is a multi-criteria decision-making mechanism invented by Thomas L. Saaty. AHP is a calculation theory using pairwise comparisons to make decisions [22]. AHP will decompose unstructured and complex multi-criteria problems into hierarchies consisting of various levels with the same goal [23]. There are adjustments made in this study in using benchmarking and AHP methods to improve marketing communication programs. According to Saaty [22], the weighting of the AHP process is carried out by expert judgment, but it is different in this study because the weighting is done by key respondents. Key respondents are individuals with a high level of knowledge or involvement with the topic under study [24]. The criteria for the key respondents in this research are individuals who have used an online travel agent that has trip \& activities facilities like Kliktrip more than 3 times.

Several previous studies that have used benchmarking and AHP methods to improve marketing communication programs are Imran et al [8], Firdhausya et al [9], Putra et al [10], and Wulandari et al [11]. Imran et al [8] utilized benchmarking and AHP methods to improve marketing communication on fashion SMEs Bearpath sandal object. On the other hand, Firdhausya et al [9] used benchmarking and AHP methods to improve marketing communication on online music 
streaming service Langit Musik object. Then, Putra et al [10] applied benchmarking and AHP methods to improve marketing communication on fashion SMEs Levaya bag object. Another relevant study was conducted by Wulandari et al [11] which explained the selection of benchmark partners using AHP on fashion SMEs Cotton.Go object.

\subsection{State of The Art}

The State of The Art in Table 3 discusses previous research related to benchmarking and AHP methods on various types of objects, but on Online Travel Agent object is still limited. Previous research used benchmarking and AHP methods to make improvements and provide decision support.

Table 3 - State of The Art

\begin{tabular}{|c|c|c|c|c|c|}
\hline No & Title & Year & Object & Author & Purpose \\
\hline 1 & $\begin{array}{l}\text { An analytic hierarchy process } \\
\text { for benchmarking of automobile } \\
\text { car service industry in the } \\
\text { Indian context }\end{array}$ & 2015 & $\begin{array}{l}\text { Automobile car } \\
\text { service industry in } \\
\text { India }\end{array}$ & $\begin{array}{l}\text { Bhupender Singh, } \\
\text { Sandeep Grover, } \\
\text { Vikram Singh, and } \\
\text { Rajesh Attri }\end{array}$ & $\begin{array}{lr}\text { AHP process } & \text { helps to } \\
\text { identify improvement } \\
\text { provide } & \text { effective } \\
\text { systematic } & \text { decision } \\
\text { support [12] } & \end{array}$ \\
\hline 2 & $\begin{array}{l}\text { Implementation of the AHP and } \\
\text { benchmarking in Strategic } \\
\text { Analysis of Polish Regions }\end{array}$ & 2015 & $\begin{array}{l}\text { Polish public } \\
\text { administration }\end{array}$ & Jacek Strojny & $\begin{array}{l}\text { AHP and benchmarking } \\
\text { methods to support the } \\
\text { presentation of strategic } \\
\text { analysis mechanisms } \\
\text { [13] }\end{array}$ \\
\hline 3 & $\begin{array}{l}\text { Exploring rural tourism and } \\
\text { sustainability in Southeast Asia } \\
\text { through the lenses of official } \\
\text { tourism websites: A } \\
\text { benchmarking exercise }\end{array}$ & 2015 & $\begin{array}{l}\text { Tourism websites } \\
\text { of five Southeast } \\
\text { Asian countries }\end{array}$ & $\begin{array}{lr}\text { Paolo } & \text { Mura and } \\
\text { Saeed } & \text { Pahlevan } \\
\text { Sharif } & \end{array}$ & $\begin{array}{l}\text { Benchmarking is used to } \\
\text { evaluate and compare } \\
\text { website quality within } \\
\text { the context of tourism } \\
{[17]}\end{array}$ \\
\hline 4 & $\begin{array}{l}\text { Competitive service quality } \\
\text { benchmarking in the airline } \\
\text { industry using AHP }\end{array}$ & 2016 & Airline industry & Alok Kumar Singh & $\begin{array}{l}\text { AHP-Service Quality } \\
\text { helps to design airline } \\
\text { competitive strategies } \\
\text { for improvement in their } \\
\text { service quality } \\
\text { performance [14] }\end{array}$ \\
\hline 5 & $\begin{array}{l}\text { Marketing Strategic Planning } \\
\text { and Choosing the Right } \\
\text { Strategy using AHP Technique }\end{array}$ & 2017 & $\begin{array}{l}\text { Ghavamin Bank } \\
\text { Mazandaran }\end{array}$ & $\begin{array}{l}\text { Forough } \\
\text { Sadeghpour, } \\
\text { Mohammad } \\
\text { Ghorbani Far, Ali } \\
\text { Ramzan Khah, } \\
\text { Masoumeh Amu } \\
\text { Akbardokht Amiri }\end{array}$ & $\begin{array}{l}\text { AHP methods to } \\
\text { determine good } \\
\text { marketing strategy [18] }\end{array}$ \\
\hline 6 & $\begin{array}{l}\text { Benchmarking Hotels: } \\
\text { Applying Analytic Hierarchy } \\
\text { Process }\end{array}$ & 2019 & Hospitality & $\begin{array}{l}\text { Awin Jabar, Savel } \\
\text { Kamal, Twezhar } \\
\text { Kamal, and Cemil } \\
\text { Top }\end{array}$ & $\begin{array}{l}\text { AHP process helps to } \\
\text { select the best hotel } \\
\text { service provider in the } \\
\text { market while the } \\
\text { benchmarking process } \\
\text { helps to compare some } \\
\text { qualities [15] }\end{array}$ \\
\hline
\end{tabular}

7 People-process-performance 2019 Cloud computing Issam Kouatli benchmarking technique in cloud computing environment an AHP approach environment
AHP and benchmark used to identify the best alternative for enhancing the motivation of intermingled people- 
$8 \quad$ Bag Marketing Communication Program Design in Levaya SMEs Using Benchmarking Method

10 Selecting Benchmarking Partners Using Analytical Hierarchy Process Approach

11 Proposed Communication
Improvement of $\begin{array}{r}\text { Program } \\ \text { Sandal Using }\end{array}$
Method Benchmarking
and Analytical Hierarchy Process Tool

12 Marketing Communication Improvement Design of Langit Musik Using Benchmarking and Analytical Hierarchy Process Tool

\section{Levaya Bag}

2020 Cotton.Go

Cotton.

Bearpath Sandal

2020

Bearpath Sandal

Farhan Ihza Imran,
Sari Wulandari,
Meldi Rendra

Bagas Praditya
Yusuf Putra, Sari
Wulandari, Boby
Hera Sagita

process competitiveness [16]

overall

Benchmarking and AHP methods help to improve marketing communication [10]

Sari Wulandari, Ardian Cahya Utama, Muhammad Arfidh

AHP process helps to determine benchmark partners which benchmark partners have the best practice in marketing communication [11]

Benchmarking and AHP methods help to improve marketing communication [8]

2020

Benchmarking and AHP
Nadya Firdhausya,
Sari Wulandari,
Boby Heru Sagita Streaming Service Sari Wulandari, help to improve Langit Musik

Based on Table 3 regarding State of The Art, it can be seen that benchmarking and AHP methods are very commonly used in various business sectors such as the automobile car service industry [12], polish public administration [13], airline industry [14], hospitality [15], cloud computing environment [16], small and medium-sized enterprise [8] [10] [11], and online music streaming [9], while in the tourism business sector, research has been carried out using the benchmarking method, but not using the AHP method and not researching related to IMC [17]. In addition, in the marketing field, the AHP method was used, but did not use the benchmarking method and did not research related to IMC [18]. Therefore, this research was conducted to provide a scientific contribution to research in the Online Travel Agent business sector with benchmarking and AHP methods related to IMC.

\section{Research Methodology}

\subsection{Research Framework}

The research framework shows the basic steps in research starting from identifying Kliktrip profile in order to determine alternative benchmark partners similar to Kliktrip. The benchmark partner determination is carried out using the AHP method. After determining the benchmark partner, the existing condition of the benchmark partner marketing communication can be identified based on key performance indicators. Key performance indicators need to be determined in advance to identify the existing condition of marketing communications from benchmark partner and Kliktrip Then, determine the marketing communication gap obtained from the results of the two existing marketing communication conditions. The last step is to determine future performance and design a marketing communication program which will be discussed at the end with Kliktrip to be adjusted to the capability of Kliktrip. The research framework in this study can be seen in Figure 2. 


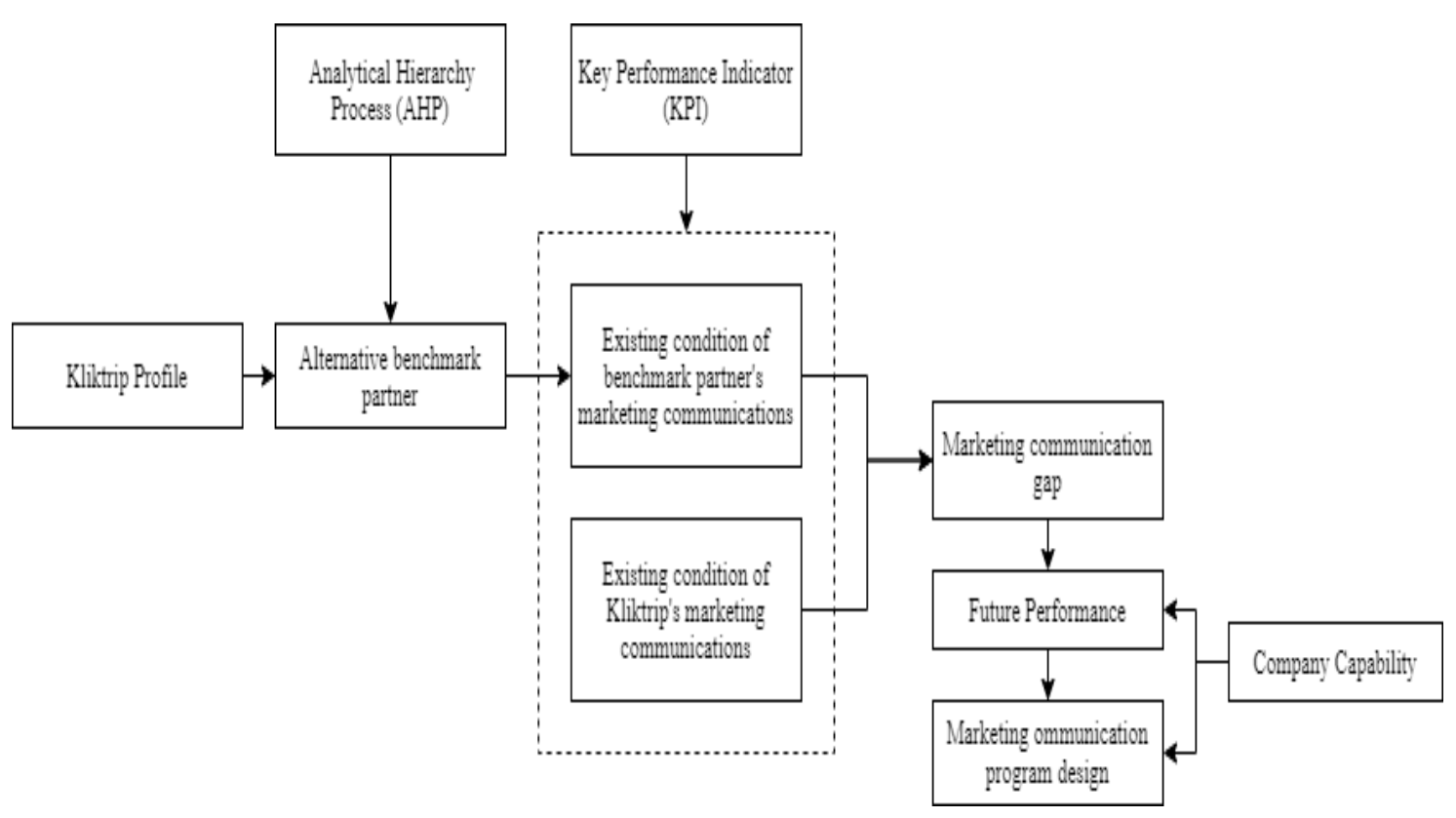

Fig. 2 - Research Framework

\subsection{Data Collection}

Data collection is divided into two types, namely primary data and secondary data. Primary data is data that comes from a researcher to answer the problem being researched and data that has been collected previously to answer the problem being studied [25]. The primary data was gathered by observing marketing communications that have been implemented by Kliktrip and benchmark partners. Besides that, distributing AHP questionnaires to determine benchmark partners is carried out online using the QuestionPro tool. The secondary data in this study are existing data of Kliktrip (Revenue data from January 2018-December 2019), the number of downloads mobile apps, the number of Instagram followers, the Instagram engagement rate, and literature study.

\subsection{Questionnaire Design}

The questionnaire in this study was designed in the form of pairwise comparison. Each attribute will be compared with one another according to the importance and the result of the comparison of each attribute will be a number from 1 to 9 [26].

The types of questions in the AHP questionnaire are closed questions so that respondents will briefly answer each of the available questions. The AHP questionnaire in this study consisted of two types of interrelated questionnaires. The questionnaire aims to determine the weight of each marketing communication mix tool dan questionnaire II aims to determine the respondents' assessment of the performance of each marketing communication mix tool that has been implemented by Mister Aladin, Explorer, and Vizitrip.

\subsection{Questionnaire Distribution}

The sampling technique used in this research is purposive sampling. Purposive sampling is a sampling technique with certain considerations [27]. The consideration referred to in this study for the questionnaire is that the respondent has used an online travel agent that has trip \& activities facilities like Kliktrip more than 3 times. The minimum number of appropriate sample sizes in a study is 30 [27], so in the questionnaire, the sample size used is 30 . Then, another consideration referred to in this Final Project for questionnaire II is that the respondent has used the online travel agent Mister Aladin/ Explorer.id/ Vizitrip. If the sample is divided into categories (for example male-female, civil-private employees, and others), the number of sample members in each category is at least 30 [27]. In questionnaire II, there are three categories of Online Travel Agent users, namely Mister Aladin user, Explorer.id user, and Vizitrip users. Shashank [28] conducted a study with a sample size of 90 respondents. Therefore, the total sample in questionnaire II is 90 respondents. 


\subsection{Data Processing}

Processing of data obtained through the AHP questionnaire was carried out using Microsoft Excel. Processing of data obtained through the AHP questionnaire was carried out using Microsoft Excel. The following are the steps for processing AHP data [14]:

a. Define the problem and structure it into a hierarchy.

b. Create a pairwise comparison matrix with a comparison scale of 1-9.

c. Priority vector calculation by dividing the elements of each column by the number of those columns. Then, get the eigenvectors by adding an element in each resulting row and dividing that number by the number of elements in the row and will assign a priority vector to the comparison matrix which gives the relative weight of each element.

d. Calculation of consistency with steps, as follows:

i. Multiply the priority vector matrix with the pairwise comparison matrix.

ii. Each element performs a comparison between the multiplication results in step (i) with the priority vector.

iii. The calculation of the $\lambda$ maximum (maximum eigenvalues) is obtained from the average results of steps (ii) of all elements.

iv. The calculation of consistency index (CI) was obtained from the formula:

$$
C I=\frac{\lambda \max -n}{n-1}
$$

v. Determination of random index (RI) in accordance with Table 4.

Table 4. Random Index

\begin{tabular}{ccccccccccc}
\hline \multicolumn{11}{c}{ Random Index (RI) } \\
\hline $\mathbf{n}$ & $\mathbf{1}$ & $\mathbf{2}$ & $\mathbf{3}$ & $\mathbf{4}$ & $\mathbf{5}$ & $\mathbf{6}$ & $\mathbf{7}$ & $\mathbf{8}$ & $\mathbf{9}$ & $\mathbf{1 0}$ \\
$\mathbf{R I}$ & 0 & 0 & 0.58 & 0.9 & 1.12 & 1.24 & 1.32 & 1.41 & 1.45 & 1.49 \\
\hline
\end{tabular}

vi. Comparison of $\mathrm{CI}$ and $\mathrm{RI}$ in a matrix will result in the value of $\mathrm{CR}$ from the formula:

$$
C R=\frac{C I}{R I}
$$

\section{Result and Discussion}

\subsection{Hierarchical Structure Design of AHP}

The first step in using the Analytical Hierarchy Process is to design a hierarchical structure that contains objectives, criteria, and alternatives. Based on Figure 3 it can be seen the hierarchical structure of AHP, there are eight criteria to determine partner benchmarks, namely advertising, sales promotion, event and experiences, public relations and publicity, online and social media marketing, mobile marketing, direct and database. marketing, and personal selling [7]. Then, there are three alternative benchmark partners, namely Mister Aladin, Explorer, and Vizitrip.

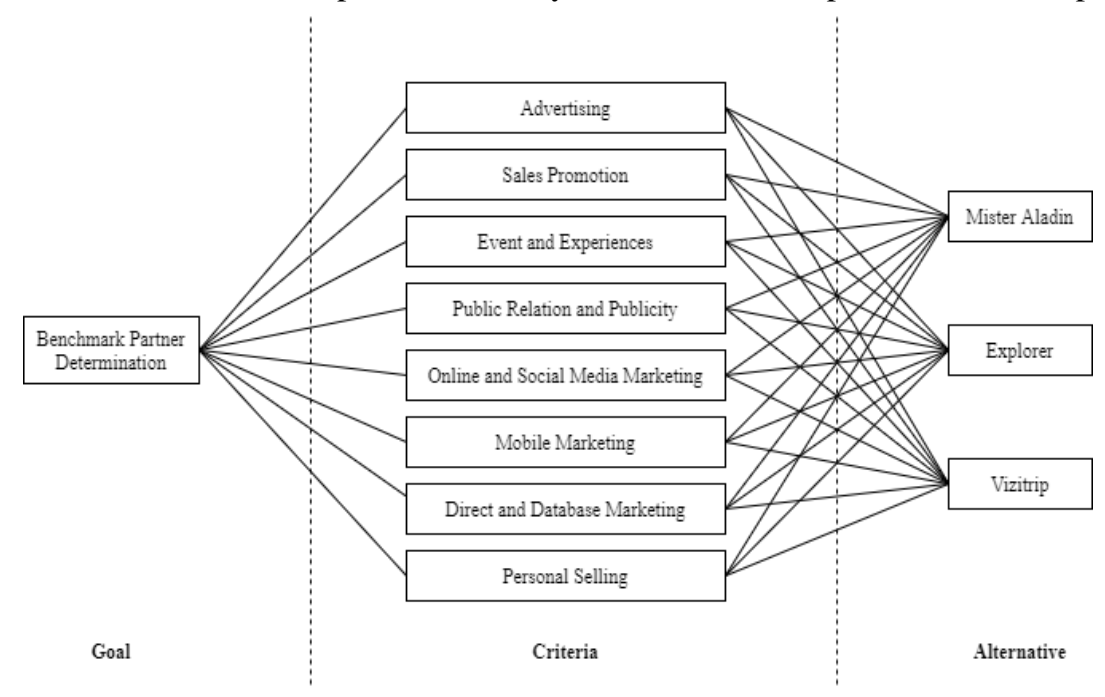

Fig. 3 - Hierarchical Structure Design of AHP 


\subsection{Marketing Communication Comparison Matrix}

The comparison matrix of the marketing communication mix is the result of the recapitulation of the questionnaire I data regarding the comparison of the interests of each marketing communication mix. Based on Table 5 it can be seen that the rankings for each AHP criterion based on the priority vector value are ordered from the highest to the lowest sequentially, as follows: online and social media marketing, sales promotion, mobile marketing, advertising, events, and experiences, direct and database marketing, personal selling, and public relations and publicity.

Table 5 - Importance Level of The Marketing Communication Criteria

\begin{tabular}{|c|c|c|c|c|c|c|c|c|}
\hline $\begin{array}{c}\text { AHP } \\
\text { Criteria }\end{array}$ & $\begin{array}{c}\text { Online } \\
\text { and Social } \\
\text { Media } \\
\text { Marketing }\end{array}$ & $\begin{array}{c}\text { Sales } \\
\text { Promotion }\end{array}$ & $\begin{array}{c}\text { Mobile } \\
\text { Marketing }\end{array}$ & Advertising & $\begin{array}{l}\text { Events and } \\
\text { Experiences }\end{array}$ & $\begin{array}{l}\text { Direct and } \\
\text { Database } \\
\text { Marketing }\end{array}$ & $\begin{array}{l}\text { Personal } \\
\text { Selling }\end{array}$ & $\begin{array}{c}\text { Public } \\
\text { Relation } \\
\text { and } \\
\text { Publicity }\end{array}$ \\
\hline $\begin{array}{l}\text { Priority } \\
\text { Vector }\end{array}$ & 0.19 & 0.17 & 0.15 & 0.13 & 0.12 & 0.10 & 0.08 & 0.07 \\
\hline
\end{tabular}

\subsection{Alternative Benchmark Partner Comparison Matrix}

The comparison matrix of alternative benchmark partners is the result of data processing from questionnaire II regarding the comparison of marketing communication performance that has been implemented by each alternative partner benchmark. Alternative benchmark partners in this study, namely Mister Aladin, Explorer.id, and Vizitrip. The satisfactional level of alternative benchmark partners in this study can be seen in Table 6 .

Table 6 - Satisfaction Level of Benchmark Partner

\begin{tabular}{ccc}
\hline AHP Criteria & Alternative Benchmark Partner & Priority Vector \\
\hline \multirow{2}{*}{ Advertising } & Mister Aladin & 0.42 \\
& Explorer.id & 0.39 \\
Sales Promotion & Vizitrip & 0.19 \\
& Mister Aladin & 0.37 \\
Events and & Explorer.id & 0.43 \\
Experiences & Vizitrip & 0.20 \\
& Mister Aladin & 0.44 \\
Public Relation and & Explorer.id & 0.40 \\
Publicity & Vizitrip & 0.16 \\
& Mister Aladin & 0.34 \\
Online and Social & Explorer.id & 0.43 \\
Media Marketing & Vizitrip & 0.23 \\
& Mister Aladin & 0.35 \\
Mobile Marketing & Explorer.id & 0.48 \\
& Vizitrip & 0.16 \\
& Mister Aladin & 0.35 \\
\cline { 2 - 3 } & Explorer.id & 0.45 \\
& Vizitrip & 0.19
\end{tabular}

Table 6 - Satisfaction Level of Benchmark Partner

\begin{tabular}{ccc}
\hline AHP Criteria & Alternative Benchmark Partner & Priority Vector \\
\hline Direct and & Mister Aladin & 0.34 \\
Database & Explorer.id & 0.47 \\
Marketing & Vizitrip & 0.19 \\
& Mister Aladin & 0.36 \\
Personal Selling & Explorer.id & 0.41 \\
& Vizitrip & 0.23 \\
\hline
\end{tabular}




\subsection{Reliability Test}

The reliability test aims to analyze the consistency of respondents' assessments [14]. Measurement of consistency can be known through the value of consistency ratio or CR. If CR $<0.10$, the assessment can be said to be consistent and vice versa if $C R>0.10$, the assessor can be said to be inconsistent so that it is necessary to redistribute the questionnaire [14].

Table 7 - Marketing Communication Mix Reliability Test

\begin{tabular}{cccc}
\hline $\boldsymbol{\lambda}$ max & CI & RI & CR \\
\hline 8.92 & 0.13 & 1.41 & 0.093 \\
\hline
\end{tabular}

Based on Table 7 it can be seen that the answers of respondents to questionnaire I regarding the comparison of interests of the marketing communication mix can be said to be consistent and can be continued to the next stage because the consistency ratio value is less than 0.1 , which is 0.093 .

Table 8 - Alternative Benchmark Partner Reliability Test

\begin{tabular}{ccccc}
\hline AHP Criteria & $\boldsymbol{\lambda} \mathbf{m a x}$ & CI & RI & CR \\
\hline Advertising & 3.042 & 0.021 & 0.580 & 0.036 \\
Sales Promotion & 3.001 & 0.001 & 0.580 & 0.001 \\
Events and Experiences & 3.047 & 0.023 & 0.580 & 0.040 \\
Public Relation and Publicity & 3.022 & 0.011 & 0.580 & 0.019 \\
Online and Social Media Marketing & 3.006 & 0.003 & 0.580 & 0.005 \\
Mobile Marketing & 3.008 & 0.004 & 0.580 & 0.007 \\
Direct and Database Marketing & 3.006 & 0.003 & 0.580 & 0.005 \\
Personal Selling & 3.004 & 0.002 & 0.580 & 0.003 \\
\hline
\end{tabular}

Based on Table 8 it can be seen that the answers of respondents to questionnaire II regarding the comparison of marketing communication performance that has been implemented by each alternative benchmark partner can be said to be consistent and can be continued to the next stage because the entire consistency ratio value is less than 0.1 .

\subsection{Benchmark Partner Determination}

Partner benchmarks are determined from the highest number of multiplications between the priority vector of the marketing communication mix and the alternative priority vector of the benchmark partner for each criterion. Based on Table 9, it can be seen that the selected benchmark partner in this study was Explorer.id because it obtained the highest priority vector multiplication value of 0.44 .

Table 9 - Benchmark Partner Ranking

\begin{tabular}{ccccc}
\hline Criteria & Weight & Explorer.id & Mister Aladin & Vizitrip \\
\hline Online and Social Media Marketing & 0.19 & 0.35 & 0.48 & 0.16 \\
Sales Promotion & 0.17 & 0.37 & 0.43 & 0.20 \\
Mobile Marketing & 0.15 & 0.35 & 0.45 & 0.19 \\
Advertising & 0.13 & 0.42 & 0.39 & 0.19 \\
Events and Experiences & 0.12 & 0.44 & 0.40 & 0.16 \\
Direct and Database Marketing & 0.10 & 0.34 & 0.47 & 0.19 \\
Personal Selling & 0.08 & 0.36 & 0.41 & 0.23 \\
Public Relation and Publicity & 0.07 & 0.34 & 0.43 & 0.23 \\
\hline & Total & $\mathbf{0 . 4 4}$ & $\mathbf{0 . 3 7}$ & $\mathbf{0 . 1 9}$ \\
\cline { 2 - 5 } & Rank & $\mathbf{1}$ & $\mathbf{2}$ & $\mathbf{3}$ \\
\cline { 2 - 5 }
\end{tabular}

\subsection{Marketing Communication Recommendations}

Recommendations for marketing communication programs and future performance are obtained from the results of knowing the gaps and the results of discussions with Kliktrip to be adjusted to the company's capabilities that can be seen in Table 10. 
Table 10 - Marketing Communication Recommendation for Kliktrip

\begin{tabular}{|c|c|c|c|c|}
\hline Platform & Tool & $\begin{array}{c}\text { Key } \\
\text { Performance } \\
\text { Indicator }\end{array}$ & Future Performance & Recommendation \\
\hline \multirow{10}{*}{$\begin{array}{l}\text { Online and } \\
\text { Social Media } \\
\text { Marketing }\end{array}$} & Website & SEO Value [7] & $\begin{array}{l}\text { SEO value on Kliktrip } \\
\text { website increased by }\end{array}$ & $\begin{array}{l}\text { Increase the number of backlinks and } \\
\text { referring domains and website speed in }\end{array}$ \\
\hline & & & $67 \%$ & $\begin{array}{l}\text { the First Contentful Paint (FCP) } \\
\text { category. }\end{array}$ \\
\hline & & Pageview [7] & $\begin{array}{l}\text { Kliktrip's pageviews } \\
\text { increased by } 100,000 \\
\text { pageviews in one year }\end{array}$ & $\begin{array}{l}\text { Promote related content that is placed in } \\
\text { the sidebar or at the bottom of the } \\
\text { information page that is currently being } \\
\text { opened by visitors. }\end{array}$ \\
\hline & & Unique Visitor & The number of & Optimizing SEO (Explanations can be \\
\hline & & {$[7]$} & $\begin{array}{l}\text { Kliktrip's unique } \\
\text { visitors increased by } \\
2,500 \text { unique visitors } \\
\text { within one year }\end{array}$ & $\begin{array}{l}\text { seen in the action plan on SEO KPIs), } \\
\text { provide a website display for the } \\
\text { desktop, and do not use pop-ups }\end{array}$ \\
\hline & TikTok & Followers [29] & $\begin{array}{llr}\text { Create a } & \text { Tiktok } \\
\text { account and get } 150 \\
\text { followers within } 6 \\
\text { months }\end{array}$ & $\begin{array}{l}\text { Provide a link to the Kliktrip Tiktok on } \\
\text { the Kliktrip Instagram Bio and } \\
\text { uploading Tiktok video content on } \\
\text { Kliktrip Instagram stories. }\end{array}$ \\
\hline & & Viewers [29] & $\begin{array}{l}\text { Create a Tiktok } \\
\text { account and video } \\
\text { content has an average } \\
\text { of } 1,000 \text { viewers in } 6 \\
\text { months }\end{array}$ & $\begin{array}{l}\text { Create a video playlist, make a title on } \\
\text { the cover of the video that builds } \\
\text { curiosity, use the relevant hashtags, } \\
\text { regularly post } 3-5 \text { videos every week, } \\
\text { and post videos during prime time. }\end{array}$ \\
\hline & & Likes [29] & $\begin{array}{l}\text { Create a Tiktok } \\
\text { account and get } 2500 \\
\text { likes within } 6 \text { months }\end{array}$ & $\begin{array}{l}\text { Create video content related to trips and } \\
\text { activities in accordance with the } \\
\text { products offered by Kliktrip and use } \\
\text { music that is currently popular and } \\
\text { ensure harmony between the tempo of } \\
\text { the song and the video }\end{array}$ \\
\hline & Webisode & $\begin{array}{l}\text { Number of } \\
\text { Episodes [19] } \\
\text { Viewers on } \\
\text { Youtube [19] }\end{array}$ & $\begin{array}{l}\text { Make } 4 \text { short film } \\
\text { episodes } \\
\text { Make short films and } \\
\text { uploading them on } \\
\text { Youtube with the } \\
\text { highest number of } \\
\text { viewers of } 129 \text { viewers } \\
\text { within } 1 \text { month }\end{array}$ & $\begin{array}{l}\text { Display a short film video at the } \\
\text { beginning when opening the link tool } \\
\text { called tap link which is listed on the } \\
\text { Kliktrip Instagram Bio, use the relevant } \\
\text { hashtag, and the duration of the short } \\
\text { film in each episode is not more than } 15 \\
\text { minutes. }\end{array}$ \\
\hline & $\begin{array}{l}\text { Video } \\
\text { Podcasting }\end{array}$ & Viewers [30] & $\begin{array}{l}\text { Make } 3 \text { podcasting } \\
\text { videos with an average } \\
\text { number of viewers of } \\
1000 \text { viewers in a } \\
\text { period of } 6 \text { months }\end{array}$ & $\begin{array}{l}\text { Types of video podcasting that can be } \\
\text { made in the form of multiple hosts and } \\
\text { interviews, the topic related to trips and } \\
\text { activities and duration are 3-6 minutes. }\end{array}$ \\
\hline \multirow[t]{2}{*}{$\begin{array}{c}\text { Sales } \\
\text { Promotion }\end{array}$} & $\begin{array}{l}\text { Cross- } \\
\text { promotion }\end{array}$ & $\begin{array}{l}\text { Number of } \\
\text { Brands [7] }\end{array}$ & $\begin{array}{l}\text { Collaborating with } 2 \\
\text { other brands }\end{array}$ & $\begin{array}{l}\text { Choose a brand that is not a competitor } \\
\text { and has a high level of popularity. Then, } \\
\text { the brand product can be } \\
\text { complementary. }\end{array}$ \\
\hline & $\begin{array}{c}\text { Contest } \\
\text { (Giveaway) }\end{array}$ & $\begin{array}{l}\text { Number of } \\
\text { Participants } \\
\text { [19] }\end{array}$ & $\begin{array}{lr}\text { Make a contest } \\
\text { (Giveaway) with a } \\
\text { total of } & 150 \\
\text { participants } & \end{array}$ & $\begin{array}{l}\text { Provide easy requirements and give an } \\
\text { attractive prize }\end{array}$ \\
\hline
\end{tabular}


Table 10 - Marketing Communication Recommendation for Kliktrip

\begin{tabular}{|c|c|c|c|c|}
\hline Platform & Tool & $\begin{array}{c}\text { Key } \\
\text { Performance } \\
\text { Indicator }\end{array}$ & Future Performance & Recommendation \\
\hline $\begin{array}{c}\text { Mobile } \\
\text { Marketing }\end{array}$ & $\begin{array}{l}\text { Mobile } \\
\text { Apps }\end{array}$ & $\begin{array}{c}\text { Rating dan } \\
\text { Reviewer [30] }\end{array}$ & $\begin{array}{l}\text { Increase the number of } \\
\text { reviewers on the } \\
\text { Kliktrip mobile apps to } \\
200 \text { reviewers within } \\
\text { one year }\end{array}$ & $\begin{array}{l}\text { Provide a search engine on the main } \\
\text { page and notification feature. Then, } \\
\text { using the app review plugin and } \\
\text { gamification. }\end{array}$ \\
\hline \multirow[t]{2}{*}{ Advertising } & $\begin{array}{l}\text { Point of } \\
\text { Purchase }\end{array}$ & $\begin{array}{c}\text { Number of } \\
\text { Downloads [5] }\end{array}$ & $\begin{array}{l}\text { Increase the number of } \\
\text { downloads on Kliktrip's } \\
\text { mobile apps to } 10,000+ \\
\text { within one year }\end{array}$ & $\begin{array}{l}\text { Provide instructions for downloading } \\
\text { mobile apps, added a swipe-up link in } \\
\text { Instagram stories, and using } \\
\text { descriptions in the App Store and } \\
\text { Google Play Store to provide important } \\
\text { information, benefits, and features }\end{array}$ \\
\hline & $\begin{array}{l}\text { Mobile } \\
\text { Billboards }\end{array}$ & $\begin{array}{c}\text { Number of } \\
\text { Vehicles (Bus) } \\
\text { [19] }\end{array}$ & $\begin{array}{l}\text { Make } 1 \text { painted vehicle } \\
\text { with a Kliktrip identity }\end{array}$ & $\begin{array}{l}\text { Using a third party to rent vacation } \\
\text { transportation in the form of a bus that } \\
\text { can be painted with a Kliktrip identity. }\end{array}$ \\
\hline $\begin{array}{l}\text { Events and } \\
\text { Experiences }\end{array}$ & $\begin{array}{l}\text { Cause- } \\
\text { related } \\
\text { Marketing }\end{array}$ & $\begin{array}{l}\text { Number of } \\
\text { Programs [7] }\end{array}$ & $\begin{array}{l}\text { Create } 3 \text { non-profit } \\
\text { social programs within } \\
6 \text { months }\end{array}$ & $\begin{array}{l}\text { Collaborate with organizations that have } \\
\text { aligned goals with Kliktrip, increase } \\
\text { public awareness of social care, and } \\
\text { upload the documentation. }\end{array}$ \\
\hline $\begin{array}{l}\text { Direct and } \\
\text { Database }\end{array}$ & $\begin{array}{l}\text { Customer } \\
\text { Service }\end{array}$ & $\begin{array}{c}\text { Operational } \\
\text { Hour [7] }\end{array}$ & $\begin{array}{l}\text { Kliktrip customer } \\
\text { service operational time }\end{array}$ & $\begin{array}{l}\text { Increase the number of customer service } \\
\text { officers by } 10 \text { people }\end{array}$ \\
\hline Marketing & & & $\begin{array}{l}\text { has increased to } 24 \\
\text { hours }\end{array}$ & \\
\hline $\begin{array}{l}\text { Personal } \\
\text { Selling }\end{array}$ & Exhibition & $\begin{array}{l}\text { Exhibition } \\
\text { Frequency [7] }\end{array}$ & $\begin{array}{l}\text { Hold exhibitions } 2 \text { times } \\
\text { a year }\end{array}$ & $\begin{array}{l}\text { Provide salespeople that have } \\
\text { knowledge about the company, } \\
\text { promotional video, brochures, company } \\
\text { identity, and entertainment in the form } \\
\text { of roulette }\end{array}$ \\
\hline $\begin{array}{l}\text { Public } \\
\text { Relation and } \\
\text { Publicity }\end{array}$ & $\begin{array}{l}\text { Influencer } \\
\text { Marketing }\end{array}$ & $\begin{array}{c}\text { Likes on } \\
\text { Instagram [31] } \\
{[32]}\end{array}$ & $\begin{array}{l}\text { Collaborate with } \\
\text { influencers and get } \\
6,000 \text { likes from content } \\
\text { uploaded by influencers }\end{array}$ & $\begin{array}{l}\text { Choose influencers with high } \\
\text { popularity, who have an interest in } \\
\text { traveling, and have a good quality } \\
\text { engagement rate. }\end{array}$ \\
\hline
\end{tabular}

The results of the recommendations for the design of the marketing communication program in table 10 are carried out by optimizing the tools in each marketing communication mix. In addition, each marketing communication mix has formulated quantitative key performance indicators so that measurable and objective targets can be determined. KPIs are formulated based on the results of previous relevant research study literature, including the value of SEO, page views, and unique visitors on the website, number of cross-promotion brands, number of cause-related marketing programs, customer service operational time, and frequency of participating in exhibitions [7]. Then, the number of followers, viewers, and likes on Tiktok [29], the number of episodes and webisode viewers, the number of contest participants, the number of mobile billboards vehicles [19], the number of ratings and reviewers on mobile apps [30], the number of downloads on mobile apps [5], and the number of likes for influencer marketing posts [31] [32].

\section{Conclusion}

The results of this study indicate that Kliktrip has not implemented effective marketing communications because it does not have a good influence on revenue and brand awareness (popularity) so it is necessary to improve marketing communications using benchmarking and AHP methods to increase revenue and brand awareness on Kliktrip. The benchmarking method is used to determine the best practices of competitors, while the AHP method is used to follow benchmark partners. Based on the results of the questionnaire data processing, it was found that the selected benchmark partner in this study was Explorer.id. Then, the best practices that have been carried out by Explorer.id are used as a reference for designing improvements to marketing communication recommendations in this study. Marketing communication program recommendations for Kliktrip, including increasing the value of SEO, page views, and unique visitors on the website, creating a Tiktok account, webisode, and video podcasting, collaborating with cross-promotion and influencer, making contests (giveaways), increasing the number of downloads and reviewers on mobile apps, 
implementing mobile billboards and cause-related marketing, increasing customer service operational time, and participating in exhibitions.

It is undeniable that this study has limitations, the sample size used in this study is only in accordance with the minimum feasible sample size. Therefore, in future research, it is possible to distribute the AHP questionnaire with a larger sample size in order to get better results. This research can also be a reference for further research that will use benchmarking and AHP methods with Online Travel Agent objects.

\section{Disclaimer}

The authors whose names are written certify that they have no conflict of interest.

\section{References}

[1] N. Maarif, "Pariwisata Sudah Sumbang US\$ 19,29 Miliar untuk Devisa Indonesia," Agustus 2019. [Online]. Available: https://travel.detik.com/travel-news/d-4669424/pariwisata-sudah-sumbang-us-1929-miliar-untukdevisa-indonesia.

[2] Y. Pusparisa, "Sektor Bisnis Startup yang Terkena Dampak Corona," 13 April 2020. [Online]. Available: https://databoks.katadata.co.id/datapublish/2020/04/13/sektor-bisnis-startup-yang-terkena-dampak-corona\#.

[3] D. Hidayat, "Survei Alvara: Perilaku Publik Selama Pandemi Covid-19," 13 April 2020. [Online]. Available: https://infobrand.id/survei-alvara-perilaku-publik-selama-pandemi-covid-19.phtml.

[4] C. Ermaningtiastuti, "Membangun Pengalaman Pariwisata Berkualitas setelah COVID-19," 24 April 2020. [Online]. Available: https://www.marketeers.com/membangun-pengalaman-pariwisata-berkualitas-setelah-covid$19 \%$

[5] A. Finkelstein, M. Harman, Y. Jia, W. Martin, F. Sarro and Y. Zhang, "Investigating the relationship between price, rating, and popularity in the Blackberry World App Store," Information and Software Technology, 2017.

[6] A. P. Sidik and A. A. Arman, "Measurement of Engagement Rate in Instagram," 2019.

[7] P. Kotler and K. L. Keller, Marketing Management, 2016.

[8] F. I. Imran, S. Wulandari and M. Rendra, "Usulan Perbaikan Program Komunikasi Pemasaran Sandal Bearpath Menggunakan Metode Benchmarking dan Tool Analytical Hierarchy Process," Jurnal Pro Bisnis, 2020.

[9] N. Firdhausya, S. Wulandari and B. H. Sagita, "Perancangan Perbaikan Komunikasi Pemasaran Pada Aplikasi Langit Musik Menggunakan Metode Benchmarking dan Tool Analytical Hierarchy Process," Jurnal Pro Bisnis, 2020.

[10] B. P. Y. Putra, S. Wulandari and B. H. Sagita, "Perancangan Program Komunikasi Pemasaran Tas Pada UKM Levaya Menggunakan Metode Benchmarking," JISI: Jurnal Integrasi Sistem Industri, 2019.

[11] S. Wulandari, A. C. Utama and M. Arfidh, "Selecting Benchmarking Partner Using Analytical Hierarchy Process Approach," International Journal of Innovation in Enterprise System, 2020.

[12] B. Singh, S. Grover, V. Singh and R. Attri, "An analytic hierarchy process for benchmarking of automobile car service industry in Indian context," Management Science Letters, 2015.

[13] J. Strojny, "Implementation of the AHP and benchmarking in strategi analysis of polish regions," Social and Behavioral Science, 2015.

[14] A. K. Singh, "Competitive service quality benchmarking in airline industry using AHP," Benchmarking: An International Journal, 2016.

[15] A. Jabar, S. Kamal, T. Kamal and C. Top, "Benchmarking Hotels: Applying Analytic Hierarchy Process," International Journal of Economics, Commerce and Management, 2019.

[16] I. Kouatli, "People-process-performance benchmarking technique in cloud computing environment," International Journal of Productivity and Performance Management, 2019.

[17] P. Mura and S. P. Sharif, "Exploring rural tourism and sustainability in Southeast Asia through the lenses of official tourism websites," Worldwide Hospitality and Tourism Themes, 2015.

[18] F. Sadeghpour and M. G. Far, "Marketing Strategic Planning and Choosing the Right Strategy using AHP Marketing Strategic Planning and Choosing the Right Strategy using AHP Technique (Case Study: Ghavamin Bank Mazandaran)," Dutch Journal of Finance and Management, 2017.

[19] G. E. Belch and M. A. Belch, Advertising and Promotion: An Integrated Marketing Communications Perspective, New York, 2018.

[20] O. Al-Minhas, "Effective Integrated Marketing Communication for Startup in Qatar in A Business-To-Business Context," 2018. 
[21] L. C. Carpinetti and A. M. de Melo, "What to benchmark? A systematic approach and cases," Benchmarking: An International Journal, 2002.

[22] T. L. Saaty, "Decision making with the Analytic Hierarchy Process," International Journal Of Services Sciences, 2008.

[23] T. L. Saaty, "The Analytic Hierarchy Process," 1980.

[24] I. Kelli, J. Debra, P. Virginia and E. Doug, "Emergency department waiting room nurse role: A key informant perspective," Australasian Emergency Nursing Journal, 2016.

[25] N. K. Malhotra, D. Nunan and D. F. Birks, Marketing Research, 2017.

[26] T. L. Saaty, "The Analytic Hierarchy Process In Conflict Management," International Journal of Conflict Management, 1990.

[27] Sugiyono, Metode Penelitian Pendidikan, Bandung: Alfabeta, 2019.

[28] D. Shashank, . P. I. S. Rao and A. Sailaja, "Relationship between Profile Characteristics and Knowledge level of State Agricultural University (SAU) and Farmers Practice (FP) Respondents on Nutrient management in rice," International Journal Of Scientific Progress and Research (IJSPR), 2016.

[29] J. T. Lovett, K. Munawar, S. Mohammed, BS, MD, RT(R)CT, V. Prabhu and MS, "Radiology Content on TikTok: Current Use of a Novel Video-Based Social Media Platform and Opportunities for Radiology," Current Problems in Diagnostic Radiology, 2020.

[30] K. A. Quesenberry, Social Media Strategy: Marketing, Advertising, and Public Relations In The Consumer Revolution, United Kingdom: Rowman \& Littlefield, 2019.

[31] D. Chaffey and F. Ellis-Chadwick, Digital Marketing, United Kingdom, 2016.

[32] K. E. Clow and D. Baack, Integrated Advertising, Promotion, and Marketing Communications, United Kingdom: Pearson, 2018

[33] Y. P. Xin, B. Wiles and Y.-Y. Lin, "Teaching Conceptual Model-Based Word Problem Story Grammar to Enhance Mathematics Problem Solving," The Journal of Special Education, 2008. 